\author{
ADAM MIODOWSKI \\ Instytut Historii i Nauk Politycznych \\ Uniwersytet w Białymstoku \\ e-mail: adammski@gmail.com
}

\title{
DZIAŁANIA PROPAGANDOWO-DEZINTEGRACYJNE „WOJSKÓWKI” KPRP W WOJSKU POLSKIM NA PRZELOMIE LAT 1919/1920
}

W miesiącach poprzedzających wyprawę kijowską Komunistyczna Partia Robotnicza Polski [KPRP] zintensyfikowała działania dezintegracyjne prowadzone już od blisko roku w oddziałach Wojska Polskiego. Po aresztowaniu 14 marca 1919 r., a następnie wydaleniu z kraju do Rosji Sowieckiej Stefana Żbikowskiego, a niedługo potem Edwarda Próchniaka ${ }^{1}$, poczynania te straciły na jakiś czas swój impet. Jednakże u progu decydującego rozstrzygnięcia zbrojnego w wojnie polsko-bolszewickiej polscy komuniści podjęli je z nową siłą. Już w grudniu 1919 r. KPRP otrzymała „wsparcie” ze strony kremlowskich komisarzy ludowych w ogromnej, jak na ówczesne warunki, kwocie $10 \mathrm{mln}$ rubli (w biżuterii i złocie) z przeznaczeniem na dezintegrację „struktur siłowych" ${ }^{2}$. Stanowiło to równowartość około $20 \mathrm{mln}$ ówczesnych dolarów ${ }^{3}$.

1 W przypadku obu aktywistów KPRP do wydalenia z kraju doszło w kwietniu $1920 \mathrm{r}$.

2 Akcja dezintegracyjna w Wojsku Polskim prowadzona przez „Wojskówkę”, tj. Wydział Agitacji w Wojsku KPRP była finansowana z Moskwy. KPRP nie była partią samodzielną, mająca na tyle poważne zaplecze $\mathrm{w}$ polskim społeczeństwie, aby pozyskiwać „takie” środki z dobrowolnych składek i datków jej członków. Zob. H. Klehr, J. E. Haynes, F. Firsov, The Secret World of American Communism, New Haven and London 1995, s. 24.

3 Wartość nabywcza 1 dolara amerykańskiego na przełomie lat 1919/1920 była dziesięciokrotnie wyższa niż w 2014 r. Oznacza to, że bolszewicy na działania „Wojskówki” KPRP wyasygnowali na przełomie lat 1919/1920 kwotę odpowiadającą dzisiejszym $200 \mathrm{mln}$ (!) dolarów. Szerzej o ewolucji wartości nabywczej dolara USA: M. Friedman, A. Jacobson Schwartz, A monetary history of the United States 1867-1960, Princeton 1963, s. 546. 
W oparciu o ten „kapitał” w wielu garnizonach reaktywowały się, względnie organizowały od podstaw Rady Delegatów Żołnierskich [RDŻ]. Kluczową rolę w tych poczynaniach odgrywali nadal aktywiści kapeerpowskiego Wydziału Agitacji w Wojsku [WAW], czyli „Wojskówki”“. Z doniesień policyjnych wynikało, że z ich inicjatywy powstały kolejne Rady w Warszawie oraz w ośrodkach prowincjonalnych. Wśród nich wymieniano: Białystok, Kielce, Lwów, Lublin, Łódź, Mławę, Modlin, Ostrołękę, Oświęcim, Piotrków, Przemyśl, Radom i Siedlce ${ }^{5}$. Stołeczna RDŻ w odezwach adresowanych do żołnierzy zapowiadała rychły wybuch rewolucji proletariackiej w Polsce i w związku z tym kierowała do nich wezwanie, by nie dawali się „użyć do pełnienia roli łamistrajków, katów i morderców własnych braci”. W odezwach pojawiła się też zachęta, aby „w zbliżającym się powstaniu klasy robotniczej przeciw burżuazji” wojskowi połączyli się z robotnikami i „lufy swoich karabinów skierowali przeciwko generałom, obszarnikom i fabrykantom". Podkreślano przy tym, że tylko współdziałanie z robotnikami da szansę „obalenia rządów wyzysku, gwałtu i ciemnoty”. Od podjęcia zgodnej współpracy tych dwóch grup uzależniano więc spełnienie się nadziei na „ustanowienie nowego socjalistycznego ładu sprawiedliwości, wolności i dobrobytu"'.

Innym wiodącym motywem pojawiającym się w materiałach propagandowych i agitacji bezpośredniej było zrzucanie odpowiedzialności za fiasko rokowań pokojowych ${ }^{7}$ i eskalację konfliktu między stroną polską, a bolszewikami na rząd

4 Wydział Agitacji w Wojsku (inaczej „Wojskówka”) podlegał bezpośrednio wywiadowi sowieckiemu i zajmował się szpiegostwem, sabotażem oraz terroryzmem, skierowanym przeciwko suwerenności i integralności Polski. Terroryzm uważany był przez bolszewików za jedną z form „rewolucjonizowania mas", czyli przyśpieszania wybuchu rewolucji i zdobycia władzy. Do najgłośniejszych aktów terroru (poza sabotażami dokonywanymi podczas działań wojennych w 1920 r.) należało zamordowanie Romana Orzęckiego, prof. Uniwersytetu Warszawskiego w 1923 r., a także w tym samym roku wysadzenie prochowni w Warszawskiej Cytadeli, co pociągnęło za sobą śmierć 28 osób. Członkowie „Wojskówki” dokonywali również morderstw na współpracownikach polskiej policji i nawet na osobach jedynie posądzanych o taką współpracę. W. Komar, Piętnaście tysięcy złotych, „Z pola walki" 1969, nr 1(45), s. 198-202.

5 Archiwum Akt Nowych [AAN], Ministerstwo Spraw Wewnętrznych [MSW], Pismo Ekspozytury Wydziału IV Komendy Okręgowej Policji Państwowej w Łodzi do Komend Powiatowych z 1.02.1920 r. z informacją o skali aktywności Rad Delegatów Żołnierskich na terenie kraju.

6 AAN, Rady Delegatów Robotniczych w Polsce [RDR], Komitet Wykonawczy Warszawskiej RDR Odezwa Warszawskiej Rady Delegatów Żołnierskich z kwietnia 1920 r.

7 Formalne negocjacje polsko-bolszewickie rozpoczęły się w lipcu 1919 r. Kontynuowano je do grudnia tego roku. W kluczowym okresie października i listopada 1919 ich głównym miejscem była miejscowość Mikaszewicze na Polesiu. Rozmowy w Mikaszewiczach, z uwagi na kategoryczne żądanie Polski uznania przez RFSRS niepodległości Ukrainy i nieatakowanie wojsk Petlury przez Armię Czerwoną, nie przyniosły rezultatów. 
w Warszawie. Proponowanym wiosną 1920 r. przez KPRP remedium na groźbę wybuchu konfliktu zbrojnego na wielką skalę był strajk powszechny robotników i odmowa ze strony żołnierzy udziału w przygotowywanej przez Naczelnika Państwa ofensywie na wschód. Agitacja na rzecz zawarcia pokoju trwała od wczesnej wiosny 1919 r. Odwołując się do haseł pacyfistycznych liczono, że społeczeństwo zmęczone wojną i negatywnie doświadczone jej skutkami wymusi na rządzących, podobnie jak to stało się w przypadku krajów nadbałtyckich, decyzję o rezygnacji z wszelkich projektów ofensywnych wymierzonych przeciwko Rosji Sowieckiej8.

Kluczową grupą, od postawy której w znacznej mierze zależało powodzenie tej akcji byli żołnierze Wojska Polskiego. Wywołanie w ich szeregach antywojennych nastrojów w praktyce mogło storpedować nie tylko polskie plany ofensywne, ale nawet doprowadzić do zdezorganizowania działań obronnych w przypadku agresji Armii Czerwonej na Polskę. Ubezwłasnowolnienie przeciwnika, jeszcze przed decydującym starciem, stanowiło istotę prowadzonych przez KPRP na przestrzeni wielu miesięcy działań propagandowo-dezintegracyjnych ${ }^{9}$. Elementem ją uzupełniającym była podjęta równolegle infiltracja szeregów żołnierskich. Głównym celem tych działań nie było wyłącznie pozyskiwanie informacji wywiadowczych, ale tworzenie probolszewickiej agentury wpływu. Jej zadaniem w okresie poprzedzającym starcie miało być propagowanie haseł rewolucyjnych i postaw pacyfistycznych, a w chwili wybuchu wojny wywołanie buntów żołnierskich. KPRP już we wcześniejszej fazie kampanii dezintegracyjnej otwarcie zapowiedziała intensyfikację działań wśród żołnierzy Wojska Polskiego. Na łamach „Czerwonego Sztandaru” stwierdzono m.in. „Nasza antywojenna agitacja musi głośno rozbrzmiewać i w wojsku. Musimy z najbardziej świadomych żołnierzy tworzyć grupy, które w chwili, gdy pójdziemy do generalnej bitwy, pociągną za sobą armię, staną się zawiązkiem Rad Delegatów Żołnierskich"10.

Urzeczywistnienie tych zamierzeń oznaczało w praktyce unicestwienie własnego państwa. Przynieść też musiało polskim komunistom nieuchronny skutek uboczny w postaci pogłębienia się ich alienacji na polskiej scenie politycznej, jak

8 Mowa o traktacie pokojowym zawartym 2 lutego 1920 r. w Tartu (Dorpacie) pomiędzy Estonią, a RFSRS. Patrz: J. Lewandowski, Historia Estonii, Wrocław 2002, s. 182n.

9 Akcja propagandowo-dezintegracyjna w tych ramach, w których prowadzili ją polscy radykałowie w latach 1919-1920 była kluczowym elementem ich polityki wojskowej. Charakterystykę praktycznego wymiaru poczynań w tej sferze odnaleźć można w publikacji: A. J. Leinwand, Czerwonym młotem $w$ orła białego. Propaganda sowiecka $w$ wojnie z Polskg 1919-1920, Warszawa 2008, s. 99-138.

10 „Czerwony Sztandar”, nr 1 z 1.10.1919 r. 
też $\mathrm{w}$ relacjach $\mathrm{z}$ większością elektoratu, $\mathrm{w}$ tym lewicowego ${ }^{11}$. Niewielu dawało wiarę zapewnieniom, że wojna rewolucyjna z Polską będzie prowadzona wyłącznie na płaszczyźnie klasowej, a nie w formie klasycznego podboju i że głównym motorem działania bolszewików nigdy nie była chęć podeptania suwerenności, i podporządkowania sąsiada będącego zawadą na drodze do ogólnoeuropejskiej rewolucji, a tylko pragnienie „wyzwolenia polskich mas proletariackich” $\mathrm{z}$, jak twierdzono, niedemokratycznych ram prawno-ustrojowych narzuconych przez Sejm Ustawodawczy.

Nie bacząc na to wszystko KPRP uparcie lansowała tezę, że Polacy nie powinni postrzegać bolszewików, jako nieprzyjaciół. Kogo zatem wskazywała, jako prawdziwego przeciwnika, z którym należało walczyć? „Nie masz, po co daleko wrogów szukać, tutaj są twoi wrogowie, co z ciebie krew piją. Nabijmy broń żołnierze, w pogotowiu miejmy bagnety. Bliska jest chwila, gdy trzeba będzie we własnym kraju bój stoczyć, rzucić o ziemię dzisiejszych panów Polski, wrogów ludu pracującego"12.

Skoro nieprzyjaciel był wewnątrz kraju, to walka z nim oznaczać musiała wywołanie wojny domowej. Wezwanie do jej wszczęcia stawało się więc naturalną konsekwencją odkrycia, którego dokonali polscy komuniści. Według nich stojące u granic Polski armie: 12, 14 i 16 postrzegać należało jako przyjaciól, którzy pragną pomóc „zniewolonemu polskiemu proletariatowi miast i wsi pokonać ich ciemiężycieli w osobach generałów, obszarników i fabrykantów”13. Nikt nie nagłaśniał jednak wewnątrzpartyjnych dokumentów, z których wynikało, że konsekwencją przyjęcia tego typu optyki będzie nie tylko okrojenie polskich granic, ale powtórne uzależnienie kraju od zewnętrznego ośrodka decyzyjnego. O tym, jak miało wyglądać to w praktyce Polacy przekonali się nieco później, w trakcie wymuszonych sytuacją na froncie i naciskami brytyjskimi ${ }^{14}$ rokowań mińskich.

11 J. Szczepański, Stanowisko polskich partii politycznych wobec wojny w latach 1919-1920 z Rosja Sowiecka, „Res Historica” 2004, z. 16, s. 145-165.

12 „Żołnierz-Robotnik”, nr 2 z 9 marca 1919 r.

13 Uniwersalny przykład narracji propagandowej wykorzystywanej przez agitatorów KPRP.

14 Na konferencji w Spa, premier brytyjski David Lloyd George, nieprzychylnie ustosunkowany do Polaków, przekonany o nieuchronnym zwycięstwie militarnym Armii Czerwonej i korzyściach gospodarczych płynących ze współpracy Wielkiej Brytanii z Rosją Sowiecką, wymusił na premierze Rzeczypospolitej W. Grabskim zgodę na przyjęcie tzw. linii Curzona jako linii polsko-sowieckiego zawieszenia broni oraz zgodę na rozstrzygnięcie przez Radę Ambasadorów bez udziału Polski: podziału Śląska Cieszyńskiego i to z pominięciem zarządzonego uprzednio plebiscytu; kwestii przynależności państwowej Wilna; Galicji Wschodniej; konstytucji Wolnego Miasta Gdańska i traktatu polsko-gdańskiego. Deklaracja podpisana przez W. Grabskiego w Spa spowodowała w konsekwencji dymisję jego rządu i powołanie 24 lipca 1920 Rządu Obrony Narodowej z premierem W. Witosem 
Komisarze bolszewiccy, reklamowani przez KPRP jako przyjaciele, $w$ trakcie rozmów podjętych 19 sierpnia 1920 postawili polskiej delegacji następujące warunki zawarcia traktatu pokojowego: ustanowienie granicy polsko-sowieckiej na linii Curzona, redukcja stanów osobowych Wojska Polskiego do poziomu 60000 żołnierzy, utworzenie Milicji Ludowej i udostępnienie tej formacji części posiadanych zapasów broni, przekazanie Armii Czerwonej wszystkich pozostałych zapasów broni, swobodny tranzyt przez Polskę oddziałów Armii Czerwonej, eksterytorialna linia kolejowa Białystok-Grajewo i dalej do Prus Wschodnich oraz zapłata odszkodowań wojennych na pokrycie kosztów odbudowy zniszczonych miast na Wschodzie ${ }^{15}$.

Co oznaczało dla strony polskiej przyjęcie zaproponowanych w Mińsku warunków pokojowych? Przede wszystkim wiązało się z niebezpieczeństwem przekreślenia suwerennego bytu państwowego i mogło stanowić wstęp do ustanowienia nad Wisłą Polskiej Republiki Rad ${ }^{16}$. W dłuższej perspektywie pojawiało się zaś ryzyko włączenia polskiego obszaru etnicznego w granice internacjonalistycznej republiki, w której faktyczną władzę sprawowałaby elita partii bolszewickiej. Współpracujący z nią polscy komuniści niejako w uzupełnieniu postulatów mińskich proponowali żyjącym w niepodległym państwie rodakom wszczęcie wojny domowej eufemistycznie określanej mianem „walki klas” i przeprowadzenie rewolucji w celu likwidacji odziedziczonej po zaborcach niesprawiedliwości społecznej. Te wezwania stanowiły motyw przewodni akcji propagandowej prowadzonej wiosną i latem 1920 r. po obu stronach frontu. Przekonujemy się o tym analizując treść kolportowanych wówczas często w wielotysięcznych nakładach $^{17}$ odezw, proklamacji i komunikatów sygnowanych przez KPRP, WAW,

na czele. Interesujące są przy tym kulisy tej brytyjskiej niechęci wobec Polski. Otóż w Londynie przebywała wówczas misja sowiecka pod kierownictwem Leonida Krasina i Lwa Kamieniewa deklarująca gotowość daleko idącej współpracy gospodarczej (a potajemnie finansująca antypolską kampanię propagandową - co było później powodem wydalenia L. Kamieniewa). Interesujące uwagi odnośnie „gier dyplomatycznych” prowadzonych na przełomie lipca i sierpnia 1920 r. między stronami konfliktu i dyplomatami zachodnioeuropejskimi sformułowała: K. D. Croll, Soviet-polish relations 1919-1921, Glasgov 2008, s. 170-181.

15 J. Dąbski, Pokój ryski (wspomnienia, pertraktacje, tajne układy z Joffem, listy), Warszawa 1931, s. $49-51$.

16 Zgoda na „dyktat miński” oznaczała też podważenie sensu wysiłku kilku pokoleń patriotów, wywodzących się z różnych grup społecznych, którzy walczyli na przestrzeni 123 lat o odzyskanie niepodległości.

17 Dane na temat wielotysięcznych nakładów niektórych ulotek podają sami aktywiści KPRP. Odnotowane są one w przechowywanych w Archiwum Akt Nowych „Zbiorach akt osobowych działaczy ruchu robotniczego". Patrz teczki: K. W. Łąkowskiego, T. Wojszcza, R. Lisieckiego, A. Litwina, S. Czarkowskiego, S. Bailla, J. Straszewskiego, S. Zielińskiego i in. Potwierdzają zaś zgromadzone 
RDŻ i zainstalowany w Białymstoku Polrewkom ${ }^{18}$. Zdumiewa w tym kontekście fakt, iż niewielu spośród liczących się działaczy partyjnych zwracało uwagę, że tego typu propozycje odbierane były przez szerokie rzesze społeczeństwa jako niedorzeczność. Lektura pism o charakterze urzędowym, jak też materiałów wspomnieniowych pozostawionych przez liderów KPRP pozwala wysnuć przypuszczenie, że niemal wszyscy oni ignorowali docierające doń sygnały odnośnie niedostatecznego „poziomu zrewolucjonizowania mas”. Przyjęcie tego typu postawy wynikało przypuszczalnie z przekonania o nieuchronnym zwycięstwie Armii Czerwonej w decydującym starciu z polskimi siłami zbrojnymi.

Ta niepoparta wystarczająco szeroką akceptacją społeczną pewność siebie leżała też u podstaw wielu publicznie składanych deklaracji, które w opinii Polaków dodatkowo skompromitowały ich autorów. Jakich reakcji spodziewali się ci ostatni komunikując np. rodakom: „Byliśmy i jesteśmy [w Polsce] jedyną partią obrońców Sowieckiej Rosji, gdyż jako partia rewolucji rozumiemy jej logikę i przebieg"19. Z treści raportów informacyjno-politycznych przygotowywanych na przełomie maja i czerwca 1920 r. przez agendy MSW wynikało, że wśród reakcji na tego typu deklaracje KPRP dominowały te o zabarwieniu negatywnym ${ }^{20}$. Czy zatem tylko „logika i przebieg” rewolucji nakazywały KPRP zamienić własne szeregi członkowskie w agenturalne środowisko przygotowujące grunt pod kapitulację polskiego społeczeństwa i jego wojska przed nadciągającą ze wschodu Armią Czerwoną? Zapewne wiele do powiedzenia mieli przy planowaniu tak prowadzonej kampanii polityczno-propagandowej kremlowscy protektorzy polskich komunistów. Skutkiem popełnionych wspólnie błędów o charakterze wizerunkowym było coraz częstsze porównywanie lewicowych radykałów, nie tylko na łamach prasy endeckiej, do targowiczan. Niewątpliwie utrudniało to nie tylko bieżącą działalność, ale tworzyło coś w rodzaju „czarnej legendy" przekreślającej szanse wyjścia zarówno w bliższej i dalszej perspektywie poza własny, ograniczony przecież liczebnie, krąg zwolenników i przekonania

w tymże archiwum i cytowane tu już: raporty Sekcji Politycznej Departamentu II Ministerstwa Spraw Wewnętrznych i raporty informacyjno-polityczne Biura Wywiadowczego MSW.

18 Polrewkom (ros. Польревком) - inaczej Tymczasowy Komitet Rewolucyjny Polski (TKRP). Stanowił zaczątek władz komunistycznych na terenach Polski zajętych przez Armię Czerwoną w trakcie ofensywy letniej 1920 r. Ukonstytuowany decyzją Rosyjskiej Komunistycznej Partii (bolszewików) z udziałem działaczy KPRP przebywających w RFSRS. 30 lipca 1920 r. Polrewkom ogłosił w Wilnie (a nie jak podano oficjalnie w Białymstoku) Manifest do polskiego ludu roboczego miast $i$ wsi, autorstwa Feliksa Dzierżyńskiego.

19 „Czerwony Sztandar”, nr 5 z 1.05 .1920 r.

20 AAN, MSW, Raporty informacyjno-polityczne Biura Wywiadowczego MSW z ostatniego tygodnia maja i czerwca $1920 \mathrm{r}$. 
do swoich idei także tych dotąd nieprzekonanych. Nim jednak działający nad Wisłą polscy sojusznicy bolszewików dostrzegli własne niezręczności jeszcze przez wiele miesięcy nie korygowali dotychczasowej strategii i starali się urzeczywistnić pierwotne zamierzenia.

Czynnikami sprzyjającymi $\mathrm{w}$ ich realizacji były zarówno manifestowane przez część żołnierzy postawy pacyfistyczne, jak też niesnaski między nimi a oficerami, do których dochodziło najczęściej na tle socjalnym. Spodziewano się, że umiejętne wykorzystywanie tych okoliczności może ułatwić indoktrynację rewolucyjną. $Z$ wezwania do walki o pokój i zapewnień o przyjaznych intencjach ze strony Rosyjskiej Federacyjnej Socjalistycznej Republiki Sowieckiej [RFSRS] wobec Polski próbowano uczynić coś w rodzaju wytrycha propagandowego, przy pomocy którego spodziewano się poszerzyć szeregi wojskowych optujących za demobilizacją i rozbrojeniem. Przeciwne temu polskie elity i kadrę oficerską prezentowano, jako wyrazicieli polityki ekspansjonistycznej zmierzającej do podeptania „idei samostanowienia narodów” i podporządkowania Polsce wschodnich sąsiadów. Konsekwencją narzucenia takiej „optyki” oceny rzeczywistości było rozpowszechnianie się wśród niektórych wojskowych poglądu, że ich własna ojczyzna była agresorem, a „miłujący pokój Kraj Rad” ofiarą w toczącej się wojnie. Od tego był już tylko krok do wytworzenia się w świadomości żołnierzy i rozpowszechnienia opinii, że w Wojsku Polskim istniał podział na dwie przeciwstawne grupy. Pierwsza $\mathrm{z}$ nich to „my” - czyli żołnierze niechętni kontynuowaniu wojny, zaś druga to „oni” - czyli oficerowie prący do decydującego starcia z Armią Czerwoną. Przeniesienie tego podziału ze sfery świadomości do codziennej rzeczywistości stwarzało dla KPRP szansę wywołania na tyle głębokiej dezintegracji w armii, że w momencie starcia z czerwonoarmistami nie byłaby ona zdolna stawić skutecznego oporu.

Podsycaną przez agitatorów dychotomię potęgowały trudności egzystencjalne, z którymi borykali się na co dzień żołnierze. Wybuchające na tym tle konflikty między przełożonymi a podwładnymi umiejętnie wyzyskiwali agitatorzy. $Z$ jednej strony interpretując te niedogodności, jako jeszcze jedno potwierdzenie lansowanego przez siebie podziału na „my” i „oni”, a z drugiej wykorzystując te sytuacje do zareklamowania alternatywy w postaci „partnerskich” relacji panujących jakoby między służącymi w Armii Czerwonej ${ }^{21}$. W ten sposób dążono do

21 Był to, rzecz jasna, mit. Przekonać się o tym można wertując nawet politycznie poprawne publikacje sowieckie. Patrz: S. Klackin, Na zaščitie oktiabrja. Organizacija riegularnoj armii i milicjonnoje stroitelstvo v sovietskoj riespublikie (1917-1920), Moskva 1965; L. Žarov, Centralnyje organy formirowanija internacjonalnych častiej Krasnoj Armii. Internacjonalnyje časti i sojedinienija na frontach 
wytworzenia kolejnego stereotypu, który miał za zadanie wpływać na świadomość i opinie żołnierzy. Sprowadzał się on do lansowania prostej przeciwstawności w postaci przypisywania Wojsku Polskiemu cech negatywnych, a Armii Czerwonej pozytywnych. Utrwalenie się takiego schematu miało za zadanie przełamać opór przed podjęciem trudnej decyzji o dezercji i przejściu na stronę „broniących pokoju” bolszewików.

O skuteczności działań indoktrynacyjnych prowadzonych w powyżej zarysowanych ramach najlepiej przekonać się sięgając po materiały wspomnieniowe tych, którzy byli przedmiotem manipulacji. Analizując relacje stacjonujących w Kielcach żołnierzy 1 oraz 2 Kompanii Rekruckiej z 4 Pułku Piechoty łatwo się zorientować, jakie panowały wśród nich nastroje u progu decydującego starcia z bolszewikami. Spróbujmy je ocenić na podstawie atmosfery, w jakiej obchodzone były wczesną wiosną 1920 r. imieniny Naczelnika Państwa. Ze wspomnianych relacji wynika, że na tle egzaltacji oficerów o rodowodzie legionowym i peowiackim postawa żołnierzy stanowiła nadzwyczaj mocny kontrast. Jeden z nich tak scharakteryzował zachowanie własne i kolegów. „Nasz nastrój był zimny, nawet nie krzyknęliśmy «niech żyje», gdyż żołnierzom nie mogło przeleźć przez gardło: nasz Piłsudski"22.

Z dalszej części analizowanych materiałów wynika, że na kilka tygodni przed wyprawą kijowską nasiliły się przypadki dezercji, a oficerowie raportowali o wyraźnym rozluźnieniu się dyscypliny wojskowej w niektórych oddziałach. Jeden z żołnierzy frontowych charakteryzując sytuację w swojej jednostce poczynił następujące obserwacje. „Młodzież nasza, która z takim zapałem opuszczała mury szkolne, kiedy przekonała się, co to jest walka na froncie, stara się teraz jak najprędzej wydostać stąd. Starają się o posady w biurach byle dalej od frontu, albo uciekają. Do inteligentów kolegów żołnierze odnoszą się z nieufnością, nawet stronią od nich, gdy wyrażają się o oficerach, bo boją się, aby ktoś z młodzieży słyszał. Na froncie żołnierze nie salutują wcale oficerom i w ten sposób za złe traktowanie odpłacają się oficerom"23. Defetyzm, którym dotknięta została część wojskowych nie był podsycany wyłącznie z zewnątrz przez cywilnych agitatorów WAW. Ale podobnie, jak to miało miejsce wcześniej jeszcze przed aresztowa-

graždanskoj wojny, [w:] Internacjonalisty $v$ bojach za vlast' sovietow. Trudiaščijesia zarubiežnych stran - učastniki bor'by za wlast' Sovietov, Moskva 1967.

22 „Żołnierska Dola”, nr 4 z 10.05.1920 r. O ukazującej się w interesującym nas okresie prasie komunistycznej przeznaczonej dla żołnierzy oraz jej walorach poznawczych pisze: J. Pytel, Polska prasa wojskowa 1914-1921. Powstanie, rozwój i jej miejsce w życiu politycznym, Toruń 2002, s. 87-89.

„Żołnierz-Robotnik”, nr 2 z 9.03.1919 r. 
niem Stefana Żbikowskiego i Edwarda Próchniaka, tak i w pierwszej połowie 1920 r. po odbudowaniu w koszarach struktur „Wojskówki” intensywną indoktrynację prowadzili od wewnątrz skierowani do szeregów armii agitatorzy. Ich działalność przynosiła mnóstwo szkód tak w wymiarze moralno-personalnym, jak też wywiadowczo-dywersyjnym. Monitorowanie poczynań tego typu osób i usuwanie z szeregów Wojska Polskiego przebiegało w niektórych przypadkach dość opornie. Dobrą tego ilustracją był przypadek aresztowanego dopiero w sierpniu 1920 r. szer. Stanisława Czarkowskiego, który zorganizował i kierował rewolucyjną komórką żołnierską w 1 Pułku Czołgów w Łodzi.

$Z$ racji na lojalność grupową większa część żołnierzy, nawet jeśli przeciwna była hasłom rewolucyjnym, z rzadka decydowała się na denuncjację ich propagatorów. Z kolei oficerom ze względu na fakt niepozostawania $\mathrm{z}$ szeregowcami w bliższej konfidencji sporo czasu zajmowało wyśledzenie podejrzanych zachowań niektórych swoich podwładnych. Działo się tak, pomimo że już w marcu 1919 r. ukazało się specjalne zarządzenie, w którym nakazano „(...) w każdej samoistnej komendzie - pułku, oddziale sanitarnym, którego dowódcą jest oficer sztabowy, wyznaczyć odpowiednio wykwalifikowanego oficera, którego zadaniem będzie: bacznie śledzić i obserwować próby przeszczepienia odnośnej propagandy w wojsku, zwracać uwagę na towarzystwo, w którym żołnierze przestają i osoby cywilne, z którymi się stykają - nurtującym opiniom wrogim do ładu i porządku natychmiast czynnie przeciwdziałać - uświadamiając jednocześnie odnośnych o wielkim niebezpieczeństwie, jakie z tego dla nowo tworzącego się państwa wyniknąć może; bibułę agitacyjną - materiały propagandy, na którą się natkną, natychmiast drogą służbową do oddziałów wywiadowczych kierować; periodycznie ze stanu roboty - nastroju w wojsku - zaobserwowanych szczegółach - własnych projektach dokładne raporty przesyłać" ${ }^{24}$. Obarczonych tymi obowiązkami oficerów zgodnie z zaleceniami naczelnych władz wojskowych mieli wspierać wytypowani szeregowcy o potwierdzonej lojalności. Ich zadaniem było wychwytywanie wszelkich sygnałów o prowadzonej przez KPRP wśród wojskowych indoktrynacji i przekazywanie uzyskanych informacji oficerom odpowiedzialnym za zabezpieczenie sił zbrojnych przed infiltracją polskich komunistów ${ }^{25}$.

Ze względu na to, że tak zorganizowany system ochrony nie działał dostatecznie sprawnie, i to głównie z winy kadry dowódczej, 1 października 1919 r. ówczesny minister spraw wojskowych gen. Józef Leśniewski wydał w formie rozkazu nowe

24 Tamże.

25 I. Pawłowski, Polityka i działalność wojskowa KPP 1918-1928, Warszawa 1964, s. 154. 
„Zalecenia w sprawie zwalczania agitacji komunistycznej w wojsku”. Wśród nich znalazły się wezwania skierowane do ogółu korpusu oficerskiego, aby złagodzić podejście do szeregowych żołnierzy i jednocześnie zaprzestać ostentacyjnej konsumpcji, zwłaszcza tej połączonej z pijaństwem. Oczekiwano, że oficerowie swój czas wolny zechcą w jakimś stopniu poświęcić żołnierzom, aby w ten sposób także na stopie pozasłużbowej wytworzyć się mogły między jedną a drugą grupą zdrowe relacje. Resortowi spraw wojskowych zależało na tym, by to oficerowie a nie agitatorzy stali się powiernikami trapionych egzystencjalnymi bolączkami żołnierzy ${ }^{26}$. Zważywszy na nastroje panujące w szeregach Wojska Polskiego w pierwszej połowie 1920 r. uznać należy, że scharakteryzowanymi powyżej środkami administracyjnymi nie można było poprawić żołnierskiego morale.

Podsycany agitacją KPRP proces dezintegracji postępował $\mathrm{w}$ armii nawet pomimo sukcesów odniesionych przez stronę polską w trakcie ofensywy kijowskiej. Pogłębił się jeszcze bardziej w pierwszej fazie walk odwrotowych ${ }^{27}$. Problem był już na tyle poważny, że stał się przedmiotem debat w gronie członków i doradców Rady Obrony Państwa [ROP]. Zatroskani niskim morale żołnierzy decydenci uznali rozwiązanie tego problemu za jedno ze swoich priorytetowych zadań $^{28}$. Przedmiotem najwyższej troski było zjawisko przybierającej stale na sile dezercji. Wedle niektórych szacunków do lipca szeregi żołnierskie porzuciło blisko 100 tys. wojskowych ${ }^{29}$. Propagowane przez agitatorów KPRP hasła pacyfistyczne w połączeniu z trudnościami egzystencjalnymi, głównie przejawiają-

26 AAN, Akta instytucji wojskowych [AIW], Zalecenia Ministra Spraw Wojskowych z 1.10.1919 r.

$27 \mathrm{~W}$ zasobie CAW zachowała się dokumentacja odzwierciedlająca morale polskich wojskowych podczas zmagań z Armią Czerwoną. Mowa tu o sprawozdaniach z inspekcji frontu (akta drugiego wiceministra spraw wojskowych), w meldunkach dywizji i brygad nadsyłanych do dowództw armii oraz w meldunkach wysyłanych przez dowództwa armii do dowództw frontów. Obfitą dokumentację obrazującą postawy żołnierzy przebywających w garnizonach, biorących udział w ofensywie kijowskiej i podczas odwrotu zawierają raporty sytuacyjne, dzienniki działań bojowych, raporty tygodniowe ze stanu organizacji dywizji piechoty, sprawozdania o stanie kompanii marszowych, instrukcje o ściganiu dezerterów, raporty o zajściach w garnizonach przechowywane w zespołach Oddziału III i V Naczelnego Dowództwa Wojska Polskiego, Dowództw Okręgów Generalnych, Departamentu Broni Głównych i Wojsk Taborowych, Oddziału I Mobilizacyjno-Organizacyjnego MSWojsk. oraz Kolekcji Rękopisów.

28 Odzwierciedlenie poczynań Rady $\mathrm{w}$ tej sferze znajdziemy $\mathrm{w}$ dokumentacji zamieszczonej w wydawnictwie, które przygotowali: A. Leinwand, J. Molenda, Protokoły Rady Obrony Państwa, [w:] Z dziejów stosunków polsko-radzieckich. Studia i materiały, t. I, Warszawa 1965, s. 145-150. O Radzie (jej składzie i aktywności) pisze: P. K. Marszałek, Rada Obrony Państwa z 1920 r. Studium prawnohistoryczne, „Seria: Acta Universitatis Wratislaviensis”, nr 1719: Prawo, t. CCXXVIII), Wrocław 1995, s. 64-112.

29 E. V. d'Abernon, Osiemnasta decydująca bitwa w dziejach świata pod Warszawa 1920 roku, Warszawa 1932, s. 53. 
cymi się w niedożywieniu, potęgowały jeszcze bardziej to naturalne zjawisko w dobie przedłużającej się wojny i chaosu na tyłach. Jak informował członków ROP gen. Tadeusz Rozwadowski w trakcie rutynowych działań żandarmerii tylko w rejonie Białegostoku zatrzymano na przestrzeni kilku dni aż 800 dezerterów $\mathrm{z}$ jednostek frontowych ${ }^{30}$. W formacjach tyłowych sytuacja była niewiele lepsza. Z jednego z raportów Biura Wywiadowczego MSW wynikało np., że z 1 Batalionu Saperskiego stacjonującego na Mokotowie codziennie dezerterowało od 3 do 5 szeregowców ${ }^{31}$. Prawdziwym wstrząsem była jednak informacja, że doszło do pierwszych przypadków przechodzenia mniejszych oddziałów na stronę bolszewicką ${ }^{32}$.

Podejmowane próby doraźnego uzupełniania stanów osobowych nie zawsze przynosiły oczekiwane rezultaty. Wśród poborowych, a nawet ochotników deklarujących chęć zaciągu do Wojska Polskiego, również działali agitatorzy KPRP coraz częściej przekonując rekrutów, że wojna przez Polskę już była przegrana, a zatem bez konsekwencji mogą zignorować wezwania werbunkowe. Generał Antoni Symon w trakcie narady wyższej kadry dowódczej poświęconej m.in. temu problemowi, tak charakteryzował sytuację na terenie kierowanego przez siebie Dowództwa Okręgu Generalnego Kraków: „Co się tyczy ludzi to trzeba stwierdzić, że ludzie nie napływają. Sprawa idzie nadzwyczaj opornie. W powiatach szerzy się szalona agitacja, ludzie stamtąd prawie wcale nie stają [na wezwanie komisji poborowych]. Więc nie mam ludzi. (...) nie będzie dwudziestu pięciu procent [poborowych] bo jest silna agitacja przeciw poborowi. Sytuacja jest tak nie pomyślna, że nie wiem czy skompletuję marszówki”"33. Z tajnego komunikatu Sztabu Generalnego wynikało, że podobnie sytuacja wyglądała w sąsiednim Dowództwie Okręgu Generalnego Kielce.

30 AAN, Kancelaria Cywilna Naczelnika Państwa w Warszawie [KCNP], Dokumentacja obrazująca działalność agitatorów komunistycznych w Wojsku Polskim.

31 Na posiedzeniu Rady Obrony Państwa [ROP] w dniu 20 lipca1920 r. poseł A. Chądzyński zaproponował, jako remedium na zjawisko dezercji ogłoszenie w kraju stanu wyjątkowego i wprowadzenie w życie ustawodawstwa „o solidarnej odpowiedzialności za ukrywanie dezerterów”. Patrz: AAN, Rada Obrony Państwa w Warszawie [ROP], Protokół posiedzenia w dniu 20 lipca1920 r.

32 Wedle sprawozdania płk. W. Maksymowicza w lipcu $1920 \mathrm{r}$. na stronę przeciwnika przeszła znaczna część żołnierzy dwóch pułków piechoty, tj. 101 i 106. Patrz: CAW, I.301.7: Oddział I Naczelnego Dowództwa Wojska Polskiego [I Oddział NDWP], t. 94. Wcześniejsze przypadki o nieco mniejszej skali odnotowuje dokumentacja resortu spraw wewnętrznych. Patrz: AAN, MSW, Raport informacyjno-polityczny Biura Wywiadowczego MSW z 18 marca1919 r. Analogiczne doniesienia odnajdujemy też w materiałach drugiego z resortów siłowych: CAW, I.300.76: Oddział II Sztabu Ministerstwa Spraw Wojskowych [II Oddział Sztabu MSWoj.], t. 14 i t. 60.

33 Wypowiedź tę przywołuje: I. Pawłowski, dz. cyt., s. 147. 
Szukając sposobu odwrócenia tych niepokojących trendów sztabowcy proponowali, aby agitacji rewolucyjnej przeciwstawić analogiczną akcję o wydźwięku propaństwowym promującym postawy obywatelskiej odpowiedzialności ${ }^{34}$. Nie było jednak rzeczą łatwą ad hoc przygotować i przeprowadzić tego typu działania. Jeśli nawet gdzieś to się udawało, to nieraz dochodziło do kuriozalnych sytuacji, kiedy obecnym na jakimś patriotycznym zgromadzeniu agitatorom KPRP nie tylko udawało się zakłócić jego przebieg, ale wręcz przekształcić $\mathrm{w}$ wiec antywojenny i antyrządowy.

Zilustrujmy powyższą konstatację odwołując się do jednego z wielu odnotowanych w źródłach tego typu przypadków. W okolicach Krasnegostawu na Lubelszczyźnie KPRP na tyle zintensyfikowała indoktrynację wśród młodzieży przedpoborowej, że bez wsparcia ze strony wojska lokalna administracja i siły policyjne nie były w stanie uporać się z tymi poczynaniami. Agitatorzy bezceremonialnie wędrowali po terenie całego powiatu zwołując własne wiece propagandowe i rozbijając te organizowane przez lokalny samorząd. W dniu 11 lipca 1920 r. w Krasnymstawie w trakcie samorządowego wiecu patriotycznego równolegle z przemówieniami miejscowych oficjeli nawołujących młodzież do ochotniczego zaciągu w szeregi Wojska Polskiego trwała akcja ulotkowa zorganizowana przez KPRP i przemawiał jej agitator. Zwróciwszy się do zebranych próbował zdeprecjonować argumenty lokalnych notabli, zadając na koniec pytanie sformułowane w dość ironicznym tonie: „Po co mamy iść do wojska i bronić panów, przecież jesteśmy tu w Polsce niewolnikami?” Siły porządkowe podjęły próbę uciszenia nieproszonego mówcy, ale okazało się, że towarzyszyła mu grupa sympatyków, którzy w sposób zdecydowany przeciwstawili się tej interwencji. Mało tego, pewna część spośród zgromadzonych okrzykami wyrażała swoje poparcie dla aktywisty KPRP. Obawiając się wybuchu zamieszek władze miejskie i stróże prawa odstąpili od dalszych działań. Dopiero wezwany na miejsce zgromadzenia oddział żołnierzy z zapasowego 12 Pułku Ułanów zdołał rozproszyć wiecujących i aresztować aż nazbyt pewnego siebie agitatora, którym okazał się Piotr Hawryła ${ }^{35}$.

O tym, że działania indoktrynacyjne nasiliły się w pierwszej połowie $1920 \mathrm{r}$. przekonać się możemy analizując zachowane akta sądowe. Porównując liczbę wszczętych $\mathrm{w}$ tym okresie spraw przeciwko aktywistom KPRP z podobnymi

34 Tamże. Z kolei o kontragitacji w szerszym kontekście pisze: K. Paduszek, Działalność propagandowa stużb informacyjno-wywiadowczych Wojska Polskiego w czasie wojny polsko-bolszewickiej 1919-1921. Organizacja, metody, treści, Torun 2004.

35 Szerzej o aktywności przywołanego aktywisty KPRP pisze: I. Pawłowski, dz. cyt., s. 159. 
postępowaniami prowadzonymi $\mathrm{w}$ drugiej połowie $1919 \mathrm{r}$. i pierwszej połowie 1921 r. przekonujemy się nie tylko o wzroście ilościowym, ale przede wszystkim zorientować się możemy, jak bardzo zmienił się charakter stawianych zarzutów. Oskarżeni dopuszczali się, bowiem coraz poważniejszych przekroczeń kodeksowych, a w związku z tym sądy ferowały też znacznie wyższe wyroki ${ }^{36}$.

Zważywszy na zarysowaną sytuację, wszyscy członkowie ROP bez względu na reprezentowaną opcję polityczną deklarowali, że niezbędną była „(...) praca nad podniesieniem ducha w wojsku na froncie i w społeczeństwie”. Nie było jednakże zgodności, co do sposobu realizacji tego postulatu. Ówczesny wiceminister w resorcie spraw wojskowych gen. Kazimierz Sosnkowski już na pierwszym posiedzeniu ROP zaproponował, aby „Dla podniesienia ducha w wojsku uchwalić wydanie odezwy do wojska". Oponowali przeciw temu Norbert Barlicki i Maciej Rataj. Pierwszy z wymienionych zwrócił uwagę członków Rady, że nie powinna ona ze względów wizerunkowych rozpoczynać działalności od wydawania odezw, a raczej od konkretnych decyzji. Z kolei przedstawiciel ludowców argumentował, że „(...) nastroje w masach żołnierskich są takie, iż proponowana odezwa może być skierowana do oficerów, a nie do żołnierzy, którzy są bardzo zdemoralizowani”. Potrzebę wydania jakiejś proklamacji do żołnierzy w celu wzmocnienia ich morale poparł natomiast Jan Stapiński. Zgłosił nawet konkretne propozycje odnośnie do jej treści. W jego opinii w dokumencie takim należało „(...) zaznaczyć, że żołnierz uciekając [z frontu] wydaje na łup nieprzyjaciela dobytek swej rodziny, zboże, inwentarz, (...) że będzie się myśleć o losie jego rodziny, iż inwalidzi będą mieli zapewnione utrzymanie, następnie trzeba wspomnieć coś o programie”. W toku dalszej dyskusji zwyciężył pogląd zwolenników wydania odezwy. Szczególnie ważne dla takiego rozstrzygnięcia debaty było powtórne wystąpienie gen. Kazimierza Sosnkowskiego, który powołując się na własną znajomość psychologii żołnierskiej stwierdził, że dla armii „niezbędny jest wstrząs moralny”. W zaistniałej sytuacji taką rolę mogłaby spełnić pod pewnymi warunkami właśnie odezwa sygnowana przez ROP. Byłaby ona przeciwwagą dla defetystycznej propagandy KPRP, w której nacisk położono na wyeksponowanie doniesień z zaplecza frontu o strajkach, zaburzeniach i trudnej sytuacji materialnej rodzin żołnierskich. Siłę tego ostatniego głosu wzmocniła opinia Naczelnika Państwa, który przekonywał oponujących przeciwko wydaniu odezwy zwracając ich uwagę, że enuncjacja tego typu „(...) ma na celu uspokoić żołnierzy; wobec potwornych pogłosek trzeba uświadomić żołnierza, iż wszelkie

36 AAN, Archiwum Teodora Duracza [ATD], Sprawa Karola Araszkiewicza - Akt oskarżenia. 
odpowiedzialne czynniki w kraju razem zebrane będą myśleć o losie żołnierza i o tym, co mu potrzeba" ${ }^{\prime 3}$.

Jednak to nie odezwa wywołała wśród mundurowych ten pożądany „wstrząs moralny”. Poczucie jedności i przeświadczenie, że wszyscy bez względu na swoje pochodzenie społeczne i status w armii walczą o wspólną sprawę, jaką było ocalenie niepodległości pojawiło się dopiero w obliczu groźby jej utraty. Pierwsze symptomy tej fundamentalnej zmiany można było zaobserwować w końcowej fazie walk odwrotowych ${ }^{38}$, a w pełnym wymiarze po przełomie militarnym i mentalnym, jaki dokonał się nie tylko wśród wojskowych, ale w całym polskim społeczeństwie w wyniku sukcesu w Bitwie Warszawskiej. To wydarzenie i następujące po nim kolejne zwycięstwa stały się impulsem do szybszego przełamywania postrozbiorowych animozji międzydzielnicowych i utwierdzania się Polaków w przekonaniu o istnieniu łączących ich historyczno-kulturowo-tożsamościowych więzi. Jednocześnie negatywne doświadczenia zdobyte w rezultacie bezpośredniego zetknięcia się z bolszewikami zmarginalizowało wpływ „różnic klasowych" na proces odbudowy wspólnoty państwowej, narodowej i obywatelskiej. Paradoksalnie do tej metamorfozy najbardziej przyczynili się polscy komuniści i ich moskiewscy protektorzy. Dostrzeżona przez społeczeństwo w ciągu półrocznych zmagań z bolszewikami w 1920 r. dychotomia między ich werbalnymi deklaracjami a sferą codziennych praktycznych działań skutecznie obnażyła wszelkie wynaturzenia leninowskiego komunizmu.

Nim dokonał się ten niezwykły przełom świadomościowy polskie społeczeństwo, jego elity, a przede wszystkim armia musiały sprostać drugiemu na przestrzeni kilku lat niezwykle trudnemu zadaniu, jakie postawiła przed tym pokoleniem historia. Z pierwszego z nich, czyli wybicia się na niepodległość, już się wywiązano. W 1920 r. należało jeszcze ten suwerenny byt utrwalić. Trzeba było tego dokonać $\mathrm{w}$ opozycji wobec zdystansowanych do naszych aspiracji europejskich elit i części wtórującej im międzynarodowej opinii publicznej. W lipcu 1920 r. w niektórych krajach europejskich doszło do wystąpień strajkowych robotników solidaryzujących się z RFSRS w jej zmaganiach z Polską.

37 AAN, ROP, Materiały i protokoły z posiedzeń ROP. Ostatecznie ROP podjęła uchwałę, by zlecić J. Piłsudskiemu i N. Barlickiemu redakcję treści odezwy. Gotowy dokument autorzy przedłożyli radzie do zatwierdzenia.

38 Z doniesień prasowych, jakie pojawiły się w pierwszych dniach sierpnia wynikało, że „(...) włościanie i [robotnicy] podmiejscy zgłaszają się tłumnie do Warszawy, aby wstąpić do Armii Ochotniczej. Pierwsi wyruszyli włościanie z Wilanowa. Wielu z nich staje z własnymi końmi, inni przyprowadzają podwody. Również włościanie rozpoczęli obficie znosić broń, która we wsiach pozostała po Niemcach i Rosjanach”. Patrz: „Ilustrowany Kurier Codzienny” z 5 sierpnia 1920 r. 
Ta antypolska akcja była przygotowana i koordynowana przez działające na kontynencie ośrodki Kominternu ${ }^{39}$ funkcjonujące w oparciu o komunizujące frakcje partii socjaldemokratycznych ${ }^{40}$. Wykorzystując środki finansowe uzyskane od Rosyjskiej Komunistycznej Partii bolszewików [RKPb] powołano sieć „komitetów wspierania Kraju Rad”. Oprócz zorganizowania akcji strajkowych przygotowano i prowadzono na szeroką skalę działania propagandowe. W efekcie doszło do tego, że część prasy dezinformowała opinię europejską o istocie i przebiegu konfliktu, a przy okazji pośrednio wywierała presję na elity rządzące poszczególnych krajów, aby te wycofały się z projektów pomocy dla Polski. Pod wpływem zmasowanego ataku propagandowego szerokie rzesze robotników w Wielkiej Brytanii, we Francji, w Czechosłowacji i w Niemczech uwierzyły, że na gruncie rosyjskim ustanowiona została prawdziwa władza robotnicza, że stworzyła ona warunki do urzeczywistnienia socjalistycznej idei sprawiedliwości społecznej. W tym kontekście zbrojne wystąpienie Polski przeciwko temu krajowi uznano za próbą unicestwienia tej nowej formy bytu państwowego. Zmanipulowani robotnicy w krajach zachodnich byli święcie przekonani, że Polska „dobija robotnicze państwo”. Kontynent obiegło więc hasło: „Ręce precz od Rosji”.

Dodatkowym motywem strajków były nastroje pacyfistyczne. Społeczeństwa europejskie były przeciwne nowej wojnie. Obawy np. Francuzów, że ich rząd zaangażuje się militarnie w obronę Polski prowadziły do pogłębienia eskalacji napięć wewnętrznych i tak już wystarczająco mocno podsycanych przez agendy Kominternu ${ }^{41}$. Efektem poczynań tego ostatniego na Wyspach Brytyjskich była uchwała podjęta 12 sierpnia 1920 na konferencji związków zawodowych i Partii Pracy grożąca podjęciem strajku generalnego, „jeśli rząd Jego Królewskiej Mości

39 Zbitka rosyjskich słów: Коммунистический Интернационал (Kommunisticzeskij Internacionał). Organizacja zwana także III Międzynarodówką, która powstała z inicjatywy W. Lenina w Moskwie w marcu 1919 r. Została założona przez 19 partii komunistycznych, a wśród nich także KPRP. Celami strategicznymi Kominternu było propagowanie idei komunistycznych i przygotowania do światowej rewolucji. Na płaszczyźnie taktycznej chodziło o kierowanie działalnością partii komunistycznych i podporządkowania ich partii bolszewickiej. O polskim „kontekście” aktywności tej struktury w 1920 r. piszą: A. J. Leinwand, Z dziejów eksportu propagandy. Komintern w wojnie z Polskq w 1920 r., „Kwartalnik Historyczny” 2004, nr 4, s. 83-107; M. Przeniosło, KPP wobec poleceń III Międzynarodówki prowadzenia akcji wywiadowczej w Polsce, „Kieleckie Studia Historyczne” 1995, t. XIII, s. 231-238. Patrz: A. Czubiński, Ruch socjalistyczny w Europie wobec odbudowy państwa polskiego, „Kwartalnik Historyczny” 1968, z. 3, s. 621-641.

40 W trakcie ofensywy Frontu Zachodniego odbywał się w Piotrogrodzie i Moskwie II Kongres Kominternu (zakończony 10 sierpnia). Delegaci z 37 krajów rozjechali się w przekonaniu o rychłym upadku Warszawy i bliskiej perspektywie wsparcia przez Armię Czerwoną planowanej rewolucji komunistycznej w Niemczech.

41 Lęk przed uwikłaniem się w nową wojnę wynikał m.in. z tego, że Francja utraciła w pierwszej wojnie światowej $37 \%$ mężczyzn w wieku od 18 do 50 roku życia. 
nie odstąpi od prowadzenia polityki propolskiej”. Potwierdzeniem, że nie były to czcze pogróżki było powołanie ogólnokrajowego komitetu strajkowego, na którego czele stanął Ernest Bevin. Równolegle, będące filią III Międzynarodówki, Biuro Międzynarodowej Federacji Związków Zawodowych, poleciło swoim członkom, by lobbowali na rzecz ustanowienia przez władze embarga na eksport amunicji do Polski ${ }^{42}$. Propolska polityka gabinetu Davida Lloyd George'a to mit wykreowany przez lewicę brytyjską na potrzeby rozpętanej kampanii w obronie Rosji Sowieckiej. Polityk ów był nieprzychylnie ustosunkowany do Polaków. Przekonany o nieuchronnym zwycięstwie militarnym Armii Czerwonej i korzyściach gospodarczych płynących ze współpracy Wielkiej Brytanii z RFSRS pozostawał daleki od angażowania się w polityczną i militarną pomoc dla Polski ${ }^{43}$. Faktem było jednak, że przynajmniej starał się zachowywać pozory i unikał ostentacyjnego manifestowania własnych pragnień.

Tego typu skrupułów nie miały natomiast władze Niemiec i Czechosłowacji, które odpowiednio 25 lipca i 11 sierpnia, licząc na upadek sąsiada i korzystne stosunki z rządzoną przez bolszewików Rosją, zablokowały jakikolwiek tranzyt materiałów wojennych z Francji ${ }^{44}$. W Pradze nie zgodzono się też na przemarsz przez karpackie przełęcze trzydziestotysięcznego zgrupowania węgierskiego gotowego przyjść Wojsku Polskiemu ze zbrojną pomocą ${ }^{45}$. Szczególnym aktem sąsiedzkiej wrogości stała się jednak próba zatrzymania nad Wełtawą zmierzającej do Polski francusko-brytyjskiej misji wojskowo-politycznej ${ }^{46}$. W tak kształ-

42 R. Pipes, Rosja bolszewików, Warszawa 2005, s. 194. Oddziaływaniu rewolucji dokonującej się na gruncie rosyjskim na sytuację w środkowej i zachodniej Europie obszerną publikację poświęcił: A. Czubiński, Rewolucja październikowa w Rosji i ruchy rewolucyjne w Europie lat 1917-1921, Poznań 1988, passim.

43 N. Davies, Lloyd George and Poland 1919-20, "Journal of Contemporary History" 1971, vol. 6, s. 132-154. Por. późniejszą rozszerzoną do blisko 90 stron edycję tego tekstu wydaną w języku polskim w formie książkowej: N. Davies, J. Fedorowicz, Lloyd George i Polska 1919-1920, Gdańsk 2000, s. 3-89; H. J. Elcock, Britain and the Russo-Polish Frontier 1919-21, "The Historical Journal" 1969, No. 1, s. 137-154.

44 Motywy takiej postawy obu państw były też pochodną ich konfliktu terytorialnego z Polską. Największe zagrożenie dla niepodległego bytu Polski występowało ze strony Niemiec. Patrz: P. Łossowski, Groźba agresji niemieckiej na Polskę w 1919 roku, „Wojskowy Przegląd Historyczny” 1961, nr 2, s. 70-96.

45 Poza kontyngentem wojskowym Węgrzy zdecydowani byli wesprzeć Wojsko Polskie także dostawami amunicji. W tym drugim przypadku plany te udało się urzeczywistnić. Patrz: Transport amunicji do Polski przez Weegry podczas wojny polsko-bolszewickiej 1920 r. Relacja gen. dyw. Nándora Taróczego, oprac. E. L. Varga, „Przegląd Historyczno-Wojskowy” 2007, R. 8, nr 2, s. 183-194.

46 W jej składzie znajdowali się M. Weygand, E. V. D’Abernon, M. Hankey i in. Szerzej: N. Davies, Sir Maurice Hankey and the Inter-Allied Mission to Poland, July-August 1920, "The Historical Journal", 1972, No. 3, s. 553-561. 
tującej się atmosferze w sierpniu 1920 r. gdańscy dokerzy okazując lojalność ze stanowiskiem rządu w Berlinie odmówili rozładunku statków z pomocą dla Polski ${ }^{47}$. Przeciwdziałając zaistniałej sytuacji dowódca wojsk Ententy w Gdańsku gen. Richard Haking wydał rozkaz o militaryzacji portu. Uczynił to wbrew opinii sympatyzującego z gdańskimi Niemcami Komisarza Ligi Narodów Reginalda Towera $^{48}$. W rezultacie podjętych decyzji możliwe stało się rozpoczęcie wyładunku dostarczonego oręża. Do pracy tej dodatkowo zaangażowani zostali żołnierze brytyjscy stacjonujący w Gdańsku.

Utrwalanie niepodległości dokonywało się zatem nie tylko $\mathrm{w}$ opozycji wobec zdystansowanych do naszych aspiracji europejskich elit i części wtórującej im międzynarodowej opinii publicznej, ale przede wszystkim w starciu z Armią Czerwoną na polach bitewnych rozrzuconych między Wisłą a Dnieprem, jak też na froncie wewnętrznym w zmaganiach z zastępami aktywistów KPRP.

\section{ABSTRACT}

\section{The Disintegrating Actions of the Communist Party of Poland in the Polish Army at the turn of 1919 and 1920}

In the months preceding the $1920 \mathrm{Kiev}$ Operation, the Communist Party of Poland intensified the disintegrating activities in the Polish Military. The action had already been undertaken a year before. Provoking the anti-war atmosphere in the ranks of soldiers could have sabotaged not only Polish offensive plans but also could have spoilt a defensive campaign in case the Soviet Army invaded Poland.

Incapacitation of an enemy before a decisive attack was the core of disintegrating actives led by Polish communists at the turn of 1919 and 1920.

Pacific attitude manifested by a part of soldiers, as well as internal dissensions between them and officers usually against their social background were suitable factors to arrange hostile actions.

47 Postawa ta stała się jedną z przesłanek późniejszej decyzji o budowie portu gdyńskiego.

488 sierpnia 1920 nadburmistrz Gdańska H. Sahm nakłonił R. Towera do zgłoszenia wniosku o znaczącym poszerzeniu terytorium Wolnego Miasta, co ten uczynił. Postulat ten nie został jednakże zrealizowany - szerzej: N. Davies, Orzeł biały, czerwona gwiazda. Wojna polsko-sowiecka 1919-1920, Kraków 2002, s. 99. 
Skilful use of those circumstances facilitated revolutionary indoctrination the process of disintegration of the Polish army fanned by communist agitation was gradually developing despite of battles won by the Polish during the Kiev offensive. The situation went even worse while the Polish troops were retreating. The tendency changed dramatically after the successful Battle of Warsaw (1920).

Key words: communist propaganda, the disintegrating activities in the Polish Military, the internal front of the Polish-Soviet War

\section{PEЗЮME}

\section{Пропагандистская и дезинтеграционная деятельность «Военки» КРПП в польской армии на рубеже 1919-1920 гг.}

За несколько месяцев до киевского выезда Коммунистическая Рабочая Партия Польши активизировала пропагандистско-дезинтеграционную деятельность, которая велась около года в отделениях польской армии. Призывы в солдатских рядах к антивоенным настроениям на практике могли не только разрушить польские наступательные планы, а также привести к дезорганизации оборонительных действий в случае агрессии Красной армии на Польшу. Обезоруживание противника еще перед решающим боем было очень важным шагом для польских коммунистов на рубеже 1919-1920 гг. в их пропагандистско-дезинтеграционной деятельности. Благоприятными факторами в их проведении были пацифистские проявления у некоторых солдат, так и разногласия между солдатами и офицерами, которые имели место чаще всего на социальном фоне.

Ключевые слова: коммуническая пропаганда (распад польской армии), внутренный фронт польско-большевитской войны 